\title{
ANALISA CUSTOMER VALUE DAN CUSTOMER EXPERIENCE TERHADAP CUSTOMER LOYALTY DENGAN CUSTOMER SATISFACTION \\ SEBAGAI VARIABEL INTERVENING \\ (Studi Pada Waroeng Spesial Sambal Cabang Purwokerto)
}

\author{
Kuswanti Ariningsih \\ Universitas Muhammadiyah Purwokerto \\ Tri Septin Muji Rahayu \\ Universitas Muhammadiyah Purwokerto
}

\begin{abstract}
This research was based on the comptitive business condition in restaurant business that was getting more competitive, therefore the corporates had to make a new marketing strategy to stay and achieve he higher market. This research aimed to test the effect of customer value and customer experience toward customer loyalty with customer satisfaction as intervening variable.

The data were gained by questionnaire method to the 110 respondent of waroeng spesial sambal cabang purwokerto with purposive sampling. The result of the research showed that not all of the hypotheses could not be accapted. Out of the 5 (five) hypotheses accepted hypotheses. The result of $\mathrm{H1}, \mathrm{H} 2, \mathrm{H} 3$ showed that customer value and customer experience partialy and simultane affected significantly of the customer experience to customer loyalty. Sobel test showed that from both variables customer value and customer experience proved that customer vaue and customer experience had mediated effect.
\end{abstract}

Key words: customer value, customer experiece, customer satisfaction, customer loyalty

\section{ABSTRAK}

Penelitian ini dilatarbelakangi oleh kondisi persaingan bisnis dibidang usaha restoran, dari waktu ke waktu yang semakin ketat, sehingga perusahaan harus membuat strategi pemasaran baru untuk mempertahankan dan meraih pangsa pasar yang lebih tinggi. Penelitian ini bertujuan menguji pengaruh customer value, customer experience terhadap customer loyalty dengan customer satisfaction sebagai variabel intervening.

Dalam penelitian ini data diperoleh melalui metode kuesioner terhadap 110 responden konsumen Waroeng Spesial Sambal cabang Purwokerto dengan menggunakan purposive sampling. Hasil penelitian ini menunjukkan bahwa tidak semua hipotesis yang dibuat dapat diterima. Berdasarkan 5 (lima) hipotesis, semua hipotesis diterima. Hasil penelitian $\mathrm{H} 1, \mathrm{H} 2$ dan $\mathrm{H} 3$ menunjukan bahwa customer value dan customer experience secara parsial dan simultan berpengaruh signifikan terhadap customer satisfaction. H4 menunjukan bahwa customer satisfaction berpengaruh signifikan terhadap customer loyalty. Sedangkan hasil penelitian dari uji sobel (H5) menunjukan bahwa dua variabel customer value dan customer experience membuktikan customer satisfaction berpengaruh memediasi.

Kata kunci: customer value, customer experience, customer satisfaction dan customer loyalty 


\section{PENDAHULUAN}

Dunia bisnis sekarang ini terus bersaing untuk menciptakan berbagai kebutuhan konsumen yang semakin tinggi dan semakin cerdas dalam memilih kebutuhannya. Dapat dilihat dari sektor dunia usaha yang telah menjadi suatu arena persaingan dan tidak ada hentihentinya bagi perusahaan-perusahaan yang berperan di dalamnya, termasuk usaha di bidang restoran dan cafe.

Perkembangan bisnis makanan, khususnya restoran saat ini membuat persaingan semakin ketat, di mana pembisnis tidak cukup menawarkan citarasa dari makanan yang disajikan, melainkan para pembisnis juga bersaing dari segi harga, pelayanan, lokasi, suasana hingga kemudahan transaksi. Oleh karena itu, para pengusaha restoran juga harus memberikan value yang diinginkan oleh konsumennya untuk memperoleh keunggulan bersaing.

Customer Value (nilai pelanggan) merupakan nilai yang diharapkan oleh konsumen, dimana Sweeney and Soutar (2001) mengusulkan "PERVAL" untuk mengukur customer value melalui empat dimensi, yaitu emosional, sosial, kualitas atau kinerja dan harga atau nilai sebagai harapan konsumen, dari sebuah restoran. Pengalaman pelanggan dapat digunakan sebagai sebuah senjata oleh perusahaan di dalam dunia persaingan yang meningkat saat ini (Pine dan Gilmore, 1999; Shaw dan Ivens, 2002; Meyer dan Schwager, 2007). Pine dan Gilmore (1999) menyatakan bahwa perusahaan perlu untuk menciptakan pengalaman bagi setiap konsumen dan tidak hanya menciptakan produk dan memberikan pelayanan kepada konsumen.

Customer satisfaction (kepuasan pelanggan) ditentukan berdasarkan persepsi konsumen pada kinerja produk atau jasa dalam memenuhi harapan konsumennya. Kepuasan pelanggan pada sebuah restoran juga dapat dipengaruhi kualitas produk makanan dan minuman, kualitas pelayanan (service quality), pengalaman konsumen dan harga yang diberikan dari restoran tersebut. Customer loyalty (kesetiaan pelanggan) yaitu orang yang membeli secara teratur dan berulangulang. Pelanggan merupakan seseorang yang terus menerus dan berulang kali datang ke suatu tempat yang sama untuk memuaskan keinginannya dengan memiliki suatu produk atau mendapatkan suatu jasa dan membayar produk atau jasa tersebut.

Sebagai salah satu jenis usaha yang bergerak dalam bidang rumah makan atau restoran, Waroeng Spesial Sambal cabang Purwokerto tidak lepas dari persaingan bisnis yang semakin ketat. Waroeng Spesial Sambal cabang Purwokerto yang terletak di Jl. Prof. Dr Soeharso, merupakan jenis usaha franchise, yang merupakan bagian dari Waroeng Spesial Sambal pusat yang ada di Jogjakarta.

Penelitian ini merupakan replikasi dari peneltian Logiawan dan Subagio (2014) dalam penelitian yang berjudul "Analisa Customer Value terhadap Customer Loyalty dengan Customer Satisfaction sebagai Variabel Intervening pada Restoran Bandar Djakarta Surabaya". Berdasarkan uraian di atas maka permasalahan yang menjadi pusat dalam penelitian ini dapat dirumuskan sebagai berikut:

1. Apakah nilai pelanggan berpengaruh secara parsial terhadap kepuasan pelanggan pada Waroeng Spesial Sambal cabang Purwokerto?

2. Apakah pengalaman pelanggan berpengaruh secara parsial terhadap kepuasan pelanggan pada Waroeng Spesial Sambal cabang Purwokerto?

3. Apakah nilai pelanggan dan pengalaman pelanggan berpengaruh secara simultan terhadap loyalitas pelanggan pada Waroeng Spesial Sambal cabang Purwokerto?

4. Apakah kepuasan pelanggan berpengaruh secara parsial terhadap loyalitas pelanggan pada Waroeng Spesial Sambal cabang Purwokerto?

5. Apakah kepuasan pelanggan terbukti berpengaruh sebagai variabel intervening dalam nilai pelanggan dan pengalaman pelanggan terhadap loyalitas pelanggan pada Waroeng Spesial Sambal cabang Purwokerto? 


\section{TINJAUAN PUSTAKA,}

\section{Nilai Pelanggan (Customer Value)}

Zeithaml memberikan definisi atau pengertian customer value (nilai pelanggan) sebagai penilaian keseluruhan konsumen terhadap utilitas sebuah produk berdasarkan persepsinya terhadap apa yang diterima dan apa yang diberikan (dalam Tjiptono, 2005:296). Menurut Albrecht (1994), terdapat tujuh elemen yang bersama-sama membentuk infrastruktur dalam penyampaian customer value, yaitu environmental, sensory, interpersonal, procedural, deliverable, informational, dan financial. Menurut Sweeny dalam Tjiptono (2005:298), empat dimensi nilai pelanggan, diantaranya adalah: Emotional value, Social value, Quality atau performance value, Price atau value of money.

\section{Pengalaman Pelanggan (Customer Experience)}

Pengalaman pelanggan didefinisikan berasal dari satu set interaksi antara pelanggan dan produk, perusahaan atau bagian dari organisasi, yang menimbulkan reaksi. Pengalaman ini benar-benar pribadi dan menyiratkan keterlibatan pelanggan pada tingkat yang berbeda (baik secara rasional, emosional, sensorik, fisik dan spiritual). Terdapat 5 dimensi pengalaman pelanggan yang dikemukanan oleh Schmitt (1999) sebagai bentuk aplikasi pendekatan yang dapat dilakukan perusahaan untuk memberikan pengalaman kepada konsumennya. Kelima dimensi tersebut diantaranya adalah Sense, Feel, Think, Act dan Relate.

\section{Kepuasan Pelanggan (Customer Satisfaction)}

Dutka (2008,p.199) menyatakan bahwa "customer satisfaction is not just the name of department to customer satisfaction must be demonstrated throughout the company and integrated into all phases of the business". Artinya penilaian kepuasan pelanggan dapat diukur dengan menggunakan tiga atribut kepuasan pelanggan. Atribut-atribut tersebut adalah: Attributes related to product, Attributes related to service, dan Attributes related to purchase

\section{Loyalitas Konsumen (Customer Loyalty)}

Menurut Hurriyati (2008,p.129) loyalitas adalah komitmen pelanggan bertahan secara mendalam untuk berlangganan kembali atau melakukan pembelian ulang produk atau jasa terpilih secara konsisten di masa yang akan datang, meskipun pengaruh situasi dan usahausaha pemasaran mempunyai potensi untuk menyebabkan perubahan perilaku. Indikator dari loyalitas yang kuat menurut Zeithaml, Bitner dan Dwayne (2009,p.47) adalah: Continue purchasing, Recommend friends, Say positive thing.

\section{Kerangka Pemikiran}

Penulis menggambarkan bahwa dimensi pada nilai pelanggan dan pengalaman pelanggan merupakan faktor yang memberikan pengaruh terhadap kepuasan pelanggan, yang kemudian juga akan membentuk loyalitas pelanggan. Hasil penelitian terdahulu yang dilakukan oleh Logiawan dan Subagio (2014) bahwa customer value berpengruh signifikan terhadap customer loyalty dengan customer satisfaction sebagai variabel intervening. Berdasarkan uraian diatas maka dapat disusun kerangka pemikiran sebagai berikut: 


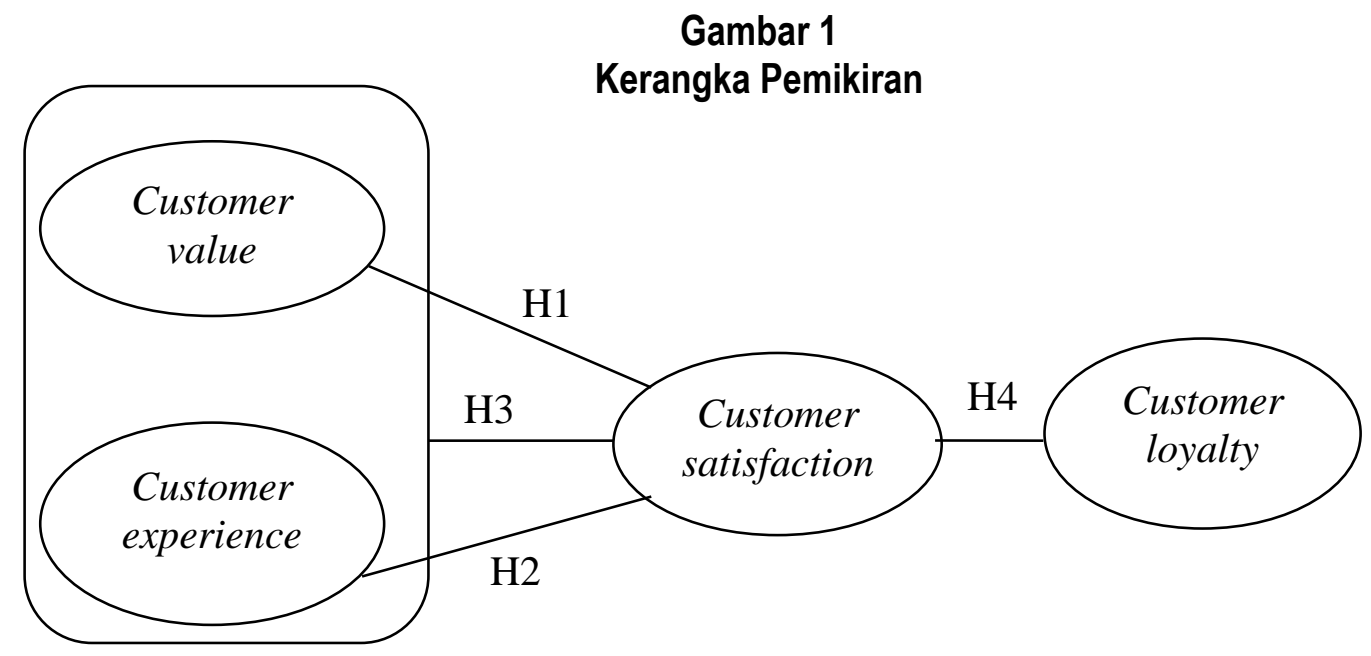

\section{Hipotesis:}

H1 : Nilai pelanggan berpengaruh secara parsial terhadap kepuasan pelanggan pada Waroeng Spesial Sambal cabang Purwokerto.

H2 : $\quad$ Pengalaman pelanggan berpengaruh secara parsial terhadap kepuasan pelanggan pada Waroeng Spesial Sambal cabang Purwokerto.

H3 : Nilai pelanggan dan pengalaman pelanggan berpengaruh secara simultan terhadap kepuasan pelanggan pada Waroeng Spesial Sambal cabang Purwokerto.

H4 : Kepuasan pelanggan berpengaruh terhadap secara parsial loyalitas pelangganpada Waroeng Spesial Sambal cabang Purwokerto.

H5: Kepuasan pelanggan terbukti berpengaruh sebagai variabel intervening dalam hubungan nilai pelanggan dan pengalaman pelanggan terhadap loyalitas pelanggan pada Waroeng Spesial Sambal cabang Purwokerto.

\section{METODE PENELITIAN}

Penelitian ini adalah penelitian dengan desain penelitian kausal yaitu untuk mengidentifikasi sebab-akibat antara variabel-varibel customer value dan customer experience terhadap customer loyalty dengan customer satisfaction yang menggunakan wawancara langsung dengan menggunakan alat bantu kuesioner kepada responden untuk memperoleh data yang dibutuhkan. Skala pengumpulan data yang digunakan dalam penelitian ini adalah Skala Likert, yaitu skala untuk mengukur sikap pendapat dan persepsi seseorang atau sekelompok orang tentang fenomena sosial. Objek penelitian ini adalah konsumen Waroeng Spesial Sambal cabang Purwokerto. Dalam penelitian ini teknik pengambilan sampel menggunakan teknik purposive sampling dengan kriteria responden berkunjung 3 kali ke atas dan berumur 17 tahun ke atas.

Metode penelitian yang digunakan adalah uji isntrumen, uji asumsi klasik, analisis regresi berganda dan sederhana, dan uji sobel. Uji instrumen meliputi uji validitas, uji reliabilitas. Uji asumsi klasik meliputi uji normalitas, uji multikolonieritas, uji heteroskedastisitas. Sedangkan analisis regresi linear berganda dan sederhana meliputi uji t, uji f, dan koefisisen determinasi $\left(R^{2}\right)$.

\section{HASIL PENELITIAN DAN PEMBAHASAN}

Berdasarkan hasil pengolahan data, penelitian ini menunjukan bahwa semua indikator yang digunakan untuk mengukur variabel-variabel yang digunakan dalam penelitian ini mempunyai 
titik signifikansinya kurang dari 0,05 berarti valid. Hasil tpenelitian ini juga menunjukkan bahwa semua variabel mempunyai Cronbach Alpha yang cukup besar yaitu di atas 0,60 sehingga dapat dikatakan semua konsep pengukur masing-masing variabel dari kuesioner adalah reliabel sehingga untuk selanjutnya item-item pada masing-masing konsep variabel tersebut layak digunakan sebagai alat ukur. Asumsi-asumsi normalitas, multikolinearitas dan heteroskedastisitas dalam model regresi dapat juga dipenuhi.

Tabel 1

Hasil uji regresi

\section{Coefficientsa}

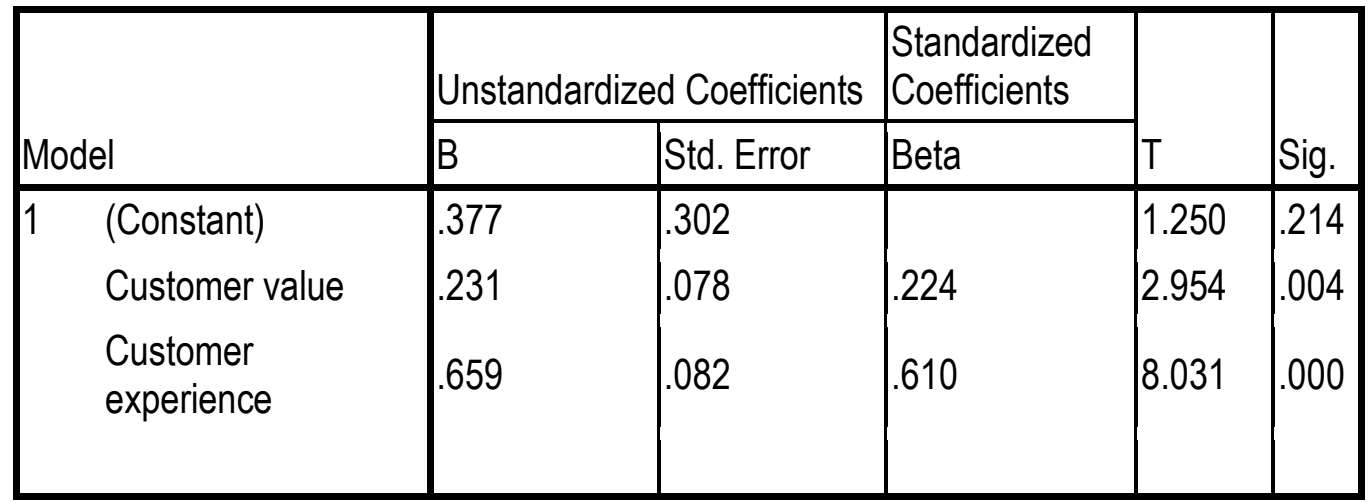

a. Dependent Variable: customer satisfaction

Tabel 2 Hasil uji regresi

Coefficients $^{\mathrm{a}}$

\begin{tabular}{|c|c|c|c|c|c|}
\hline \multirow[b]{2}{*}{ Model } & \multicolumn{2}{|c|}{ Unstandardized Coefficients } & \multirow{2}{*}{\begin{tabular}{|l} 
Standardized \\
Coefficients \\
Beta \\
\end{tabular}} & \multirow[b]{2}{*}{$\mathrm{T}$} & \multirow[b]{2}{*}{ Sig. } \\
\hline & $B$ & Std. Error & & & \\
\hline $1 \quad$ (Constant) & 1.786 & .351 & & 5.088 & .000 \\
\hline Customer satisfaction & 0.552 & .091 & .505 & 6.074 & .000 \\
\hline
\end{tabular}

a. Dependent Variable: customer loyalty

\section{HI: Nilai Pelanggan Berpengaruh terhadap Kepuasan Konsumen}

Nilai pelanggan secara parsial berpengaruh signifikan terhadap kepuasan konsumen Waroeng Spesial Sambal cabang Purwokerto dengan menggunakan batas signifikansi 0,05, nilai signifikansi tersebut lebih kecil dari taraf $5 \%$. Karena nilai t hitung $>t$ tabel $(2,954>1,982)$. Dengan demikian, maka hipotesis pertama diterima.

\section{H2: Pengalaman Pelanggan Berpengaruh terhadap Kepuasan Konsumen}

Pengalaman pelanggan secara parsial berpengaruh signifikan terhadap kepuasan konsumen Waroeng Spesial Sambal cabang Purwokerto hal ini ditunjukkan dengan dengan menggunakan batas signifikansi 0,05 , nilai signifikansi tersebut berada di bawah taraf $5 \%$ dan nilai $t$ hitung $>t$ tabel $(8,031>1,982)$, berarti Ho ditolak dan Ha diterima. Dengan demikian, maka hipotesis kedua diterima. 


\section{H3: Kepuasan Konsumen Berpengaruh terhadap Loyalitas Konsumen}

Customer satisfaction secara parsial berpengaruh signifikan terhadap customer loyalty konsumen Waroeng Spesial Sambal cabang Purwokerto dengan menggunakan batas signifikansi 0,05 , nilai signifikansi tersebut berada di bawah taraf $5 \%$. Karena nilai $t$ hitung $>t$ tabel $(6,074>$ 1,982). Dengan demikian, maka hipotesis keempat diterima.

\section{H4: Nilai Pelanggan dan Pengalaman Pelanggan Berpengaruh terhadap Kepuasan Pelanggan Tabel 3 \\ Hasil Uji Simultan (F)}

\begin{tabular}{|ll|r|r|r|r|r|}
\hline \multicolumn{1}{|l|}{ ANOVA $^{\mathrm{b}}$} \\
\hline 1 & $\begin{array}{c}\text { Sum of } \\
\text { Squares }\end{array}$ & \multicolumn{1}{c|}{ Df } & Mean Square & F & Sig. \\
\hline $1 \quad$ Regression & 18.079 & 2 & 9.039 & 72.852 & $.000 \mathrm{a}$ \\
& Residual & 13.276 & 107 & .124 & & \\
& Total & 31.355 & 109 & & & \\
\hline
\end{tabular}

a. Predictors: (Constant), Customer experience, Customer value

b. Dependent Variable: customer satisfaction

Dari hasil perhitungan statistik yang menggunakan SPSS 16 yang tertera pada Tabel 3, diperoleh nilai $F$ sebesar 72,852 dengan tingkat signifikansi 0,000 . Nilai signifikansi yang dihasilkan tersebut lebih kecil dari 0,05 dan untuk $f$ tabel untuk sampel sebanyak 110 orang, maka nilai $f$ hitung $>\mathrm{f}$ tabel $(72,852>3,081)$. Jadi dapat disimpulkan bahwa nilai pelanggan dan pengalaman pelanggan secara bersama-sama berpengaruh terhadap kepuasan konsumen di Waroeng Spesial Sambal cabang Purwokerto. Dengan demikian, maka hipotesis ketiga diterima.

\section{H5: Kepuasan Pelanggan Terbukti Berpengaruh Sebagai Variabel Intervening Dalam Hubungan Nilai Pelanggan Dan Pengalaman Pelanggan Terhadap Loyalitas Pelanggan}

Kepuasan konsumen ada pengaruh intervening hubungan antara nilai pelanggan terhadap loyalitas pelanggan ditunjukan dari uji t hitung $=2,634$ lebih besar dari $t$ tabel yaitu $=1,982$ dengan tingkat signifikansi 0.05 . Demikian pula kepuasan konsumen terbukti ada pengaruh intervening antara pengalaman pelanggan terhadap loyalitas pelanggan Oleh karena $t$ hitung $=4,604$ lebih besar dari $t$ tabel yaitu =1,982 dengan tingkat signifikansi 0,05.

\section{PEMBAHASAN}

Hasil penelitian ini menunjukan bahwa nilai pelanggan dari konsumen Woroeng Spesial Sambal cabang Purwokerto memiliki pengaruh yang signifikan terhadap kepuasan pelanggan. Hal ini terbukti pada nilai thitung $(2,954)$ lebih besar dari t tabel $(1,982)$ dengan nilai signifikansi 0,004 dengan menggunakan batas signifikansi 0,05 , yang memiliki arti bahwa jika nilai pelangganyang dirasakan konsumen yaitu rasa (makanan dan minuman), harga yang ditawarkan dan pelayanan semakin tinggi atau semakin baik, maka kepuasan pelanggan juga akan mengalami peningkatan yang signifikan. Oleh karena itu, dapat dikatakan bahwa hipotesis 1 yang menyatakan bahwa nilai pelangganberpengaruh terhadap kepuasan pelanggan terbukti benar. Secara umum, hasil penelitian ini, mendukung hasil penelitian yang dilakukan oleh Logiawan dan Subagio (2014) yang membuktikan secara empiris 
bahwa nilai pelanggandipersepsi oleh konsumen merupakan prediktor positif bagi kepuasan konsumen.

Hasil penelitian ini menunjukan bahwa pengalaman pelanggan dari konsumen Waroeng Spesial Sambal cabang Purwokerto memiliki pengaruh yang signifikan terhadap kepuasan pelanggan. Hal ini terbukti pada nilai t hitung $(8,031)$ lebih besar dari t tabel $(1,982)$ dengan nilai signifikansi 0,000 dengan menggunakan batas signifikansi 0,05 , yang memiliki arti bahwa jika pengalaman pelanggan yang dirasakan konsumen yaitu desain dan layout, variasi menu (sambal, makanan dan minuman), hingga keramahan karyawan semakin tinggi atau semakin baik, maka kepuasan pelanggan juga akan mengalami peningkatan yang signifikan. Oleh karena itu, dapat dikatakan bahwa hipotesis 2 yang menyatakan bahwa pengalaman pelangganberpengaruh terhadap kepuasan pelanggan terbukti benar. Secara umum, hasil penelitian ini, mendukung hasil penelitian yang dilakukan oleh Pramudita dan Japarianto (2013)yang membuktikan secara empiris bahwa pengalaman pelanggan dipersepsi oleh konsumen merupakan prediktor positif bagi kepuasan konsumen.

Hasil penelitian ini menunjukan bahwa kepuasan pelanggandari konsumen Waroeng Spesial Sambal cabang Purwokerto memiliki pengaruh yang signifikan terhadap loyalitas konsumen.Hal ini terbukti pada nilai t hitung $(6,074)$ lebih besar dari t tabel $(1,982)$ dengan nilai signifikansi 0,000 dengan menggunakan batas signifikansi 0,05 .Kepuasan pelanggan yang diperoleh dari nilai pelanggan dan pengalaman pelanggan dapat berkembang menjadi loyalty. Berarti jika tingkat kepuasan pelanggan semakin tinggi atau semakin baik, maka loyalitas atau loyalitas pelangganjuga akan mengalami peningkatan yang signifikan. Oleh karena itu, dapat dikatakan bahwa hipotesis 4 yang menyatakan bahwa kepuasan pelangganberpengaruh terhadap loyalitas konsumenterbukti benar. Hasil ini juga mendukung penelitian terdahulu yang dilakukan oleh Logiawan dan Subagio (2014) bahwa terdapat korelasi positif antara kepuasan pelanggan dengan loyalitas pelanggan dan bahwa kepuasan pelanggan akan mengarahkan konsumen untuk menjadi konsumen yang loyal.

Hasil penelitian berdasarkan uji sobel (sobel test) dapat diperoleh hasil thitung dari variabel nilai pelanggan (2,634), karena nilai $t$ hitungdari nilai pelangganlebih besar dari t tabel $(2,634>$ 1,982)maka terbukti bahwa kepuasan pelanggan berpengaruh sebagai variabel intervening hubungan antara nilai pelanggan terhadap loyalitas pelanggan. Hasil t hitung dari variabel pengalaman pelanggan $(4,604)$ karena nilai t hitung dari pengalaman pelanggan lebih besar dari t tabel $(4,604>1,892)$ maka terbukti bahwa kepuasan pelanggan berpengaruh sebagai variabel intervening hubungan antara pengalaman pelanggan terhadap loyalitas pelanggan. Artinya loyalitas pelanggan yang dipengaruhi oleh nilai pelanggan dan pengalaman pelanggan akan tergantung juga pada kepuasan yang dirasakan pelanggan. Hasil ini sesuaidengan penelitian terdahulu yang dilakukan oleh Logiawan dan Subagio (2014) bahwa kepuasan pelanggan terbukti sebagai variabel intervening hubungan antara nilai pelanggan terhadap loyalitas pelanggan.

Hasil penelitian menunjujkan bahwa koefisien determinasi diperoleh sebesar 0,569. Hal ini berarti $56,9 \%$ kepuasan konsumen dapat dijelaskan oleh variabel pengalaman pelanggan dan nilai pelanggan. Sedangkan sisanya $43,1 \%$ variabel kepuasan konsumen dapat dijelaskan oleh variabelvariabel lainnya yang tidak diteliti dalam penelitian ini. Kemudian dari hasil perhitungan menunjukan bahwa koefisien determinasi diperoleh sebesar 0,248. Hal ini berarti hanya 24,8\% loyalitas konsumen dapat dijelaskan oleh variabel kepuasan konsumen Sedangkan sisanya $75,2 \%$ variabel loyalitas konsumen dapat dijelaskan oleh variabel-variabel lainnya yang tidak diteliti dalam penelitian ini. 


\section{KESIMPULAN DAN SARAN}

\section{Kesimpulan}

berikut:

Berdasarkan hasil penelitian yang telah dilakukan dalam penelitian ini dapat disimpulkan sebagai

1. Secara parsial variabel nilai pelanggan dan pengalaman pelanggan berpengaruh signifikan terhadap kepuasan pelanggan.

2. Secara simultan nilai pelanggandanpengalaman pelanggan berpengaruh signifikan terhadap kepuasan pelanggan.

3. Secara parsial kepuasan pelanggan juga berpengaruh signifikan terhadap loyalitas pelanggan.

4. Dari uji sobel (sobel test) dapat diperoleh hasil bahwa dari kedua variabel independen penelitian ini menjelaskan bahwa nilai pelanggan dan pengalaman pelanggan membuktikan bahwa kepuasan pelanggan berpengaruh memediasi hubungan antara nilai pelanggan dan pengalaman pelanggan terhadap loyalitas pelanggan.

\section{Keterbatasan}

Penelitian ini juga masih memiliki keterbatasan-keterbatasan.Dengan keterbatasan ini, diharapkan dapat dilakukan perbaikan untuk penelitian yang akan datang. Adapun keterbatasan dalam penelitian ini antara lain:

1. Penelitian ini hanya menerapkan metode survei melalui kuesioner, peneliti tidak melakukan wawancara, sehingga kesimpulan yang dikemukakan hanya berdasarkan pada data yang terkumpul melalui instrumen secara tertulis.

2. Penelitian ini terbatas pada penelitian di Waroeng Spesial Sambal yang terdapat di Purwokerto, yang mengakibatkan diperolehnya hasil dan kesimpulan yang berbeda dengan objek yang lebih luas seperti kota-kota besar lainnya.

\section{Saran}

Berdasarkan pada hasil penelitian pada Waroeng Spesial Sambal cabang Purwokerto, maka penulis mencoba memberikan saran kepada pihak Waroeng Spesial Sambal cabang Purwokerto sebagai pertimbangan dan masukan bagi perusahaan dan juga bagi peneliti salanjutnya, sebagai berikut:

1. Saran untuk perusahaan

a. Untuk variabel nilai pelanggan, pada quality atau performance value memiliki nilai rata-rata terendah $(3,6)$,Waroeng Spesial Sambal cabang Purwokerto tetap harus memperhatikan dan meningkatkan kecepatan pelayanan, menanggapi komplain dari konsumen, kemampuan karyawan dalam penyampaian informasi, sikap ramah karyawan seperti selalu tersenyum saat menyambut tamu, mengucapkan terima ksaih dan memiliki inisiatif untuk selalu memberikan info kepada konsumen mengenai produk yang dimilikinya agar konsumen tidak ragu dalam melakukan pemesanan.

b. Untuk variabel pengalaman pelanggan, pada indikator relate memiliki nilai rata-rata terendah $(3,4)$, pengalaman pelanggan dapat dilakukan dengan cara memberikan pelayanan yang baik, fasilitas yang bisa dinikmati konsumen seperti wifi, maupun produk yang berbeda dengan restoran lainagar konsumen merasakan pengalaman yang menyenangkan selama berada di tempat tersebut dan mau merekomendasikan kepada orang lain.

c. Untuk kepuasan pelanggan, pada indikator attributes related to service memiliki nilai rata-rata terendah $(3,3)$,yang perlu ditingkatkan yaitu servicedengan selalu memberikan perhatian penuh kepada konsumen yang datang, khususnya konsumen yang menunggu antre. Dahulukan 
konsumen yang sudah menunggu lama untuk dapat makan di Waroeng Spesial Sambal cabang Purwokerto.

d. Untuk kepuasan pelanggan, pada indikator say positive think memiliki nilai rata-rata terendah $(3,5)$,Waroeng Spesial Sambal cabang Purwokerto perlu untuk melakukan survei berkala kepada konsumen. Dengan adanya survei secara berkala ini maka konsumen merasa diperhatikan. Selain itu dari hasil survei ini, pihak Waroeng Spesial Sambal cabang Purwokerto dapat memperbaiki segala kekurangannya sehingga dapat semakin memuaskan konsumennya dan membuat konsumen tetap loyal dan konsumen mau berbagi cerita dengan orang lain tentang pengalaman menyenangkan.

2. Saran untuk penelitian selanjutnya

a. Sebaiknya untuk penelitian selanjutnya dapat menggunakan metode wawancara dalam mendapatkan data tambahan jika diperlukan.

b. Penelitian selanjutnya dapat dilakukan dengan mengambil sampel dari beberapa perusahaan yang bergerak di bidang yang sama maupun perusahaan yang bergerak di bidang berbeda, sehingga hasilnya memungkinkan untuk dilakukan perbandingan, tidak hanya terbatas pada satu buah perusahaan saja.

c. Penelitian selanjutnya sebaiknya menambah variabel-variabel yang lain agar didapatkan hasil penelitian yang lebih menjelaskan mengenai variabel-variabel apa saja yang mempengaruhi kepuasan pelanggan, seperti: kualitas pelayanan, ikatan emosi, kepercayaan dan kemudahan.

\section{REFERENSI}

Albrecht, K. 1994. The Northbound Train: Finding the purpose, setting the direction, shaping the destiny of your organization. California, USA: American Management Association.

Dutka, Alan. 2008. AMA Hand Book for Customer Satisfaction. NTC Business Book,. Lincolnwood, llinois.

Hurriyati, Ratih. 2008. Bauran Pemasaran dan Loyalitas Konsumen. Bandung: Alfabeta

Logiawan, Yenny dan Subagio, Hartono. 2014. Analisa Customer Value terhadap Customer Loyalty dengan Customer Satisfaction sebagai Variabel Intervening pada Restoran Bandar Djakarta Surabaya:Universitas Kristen Petra.

Meyer, C., \& Schwager, A. 2007. Understanding customer experience. Harvard Business Review, 85(2), 116-126.

Pine, B.J., \& Gilmore J.H. 1999. The experience economy: Work is theatre. New York: The Free Pressand every business a stage. Boston: Harvard Business School Press.

Pramudita, Yoana Arina dan Japarianto, Edwin. (2013). Analisa Customer Value dan Customer Experience terhadap Customer Satisfaction De Kasteel Resto Surabaya: Universitas Kristen Petra.

Sweeney, J.C. and Soutar, G.N. 2001. "ConsumerPerceived Value: The Development of A Multiple item Scale," Journal of Retailing, Vol. 77, No. 2, pp. 203-220.

Tjiptono, F. 2005. Manajemen Jasa. Yogyakarta: Andi Offset.

Zeithaml, V., Bitner, M.J., dan Gremeler, D.D,. (2009). Services Marketing- integrating customer focus across the firm 5th Edition. Newyork: McGraw-Hill. 